\title{
Wyoming Big Sagebrush and Herbaceous Cover Relationships
}

\author{
Bok Sowell (Corresponding author) \\ Department of Animal and Range Sciences \\ PO Box 172900, Bozeman, MT 59717-2900, United States \\ Tel: 1-406-994-5558_E-mail: bok@montana.edu
}

Carl Wambolt

Department of Animal and Range Sciences

PO Box 172900, Bozeman, MT 59717-2900, United States

Tel: 1-406-994-5580_E-mail: cwambolt@montana.edu

Jennifer Paddock

Department of Animal and Range Sciences

PO Box 172900, Bozeman, MT 59717-2900, United States

Tel: 1-406-547-3633 ext 101 E-mail: jennifer.paddock@mt.usda.gov

\author{
Vanessa Lane \\ Department of Animal and Range Sciences \\ PO Box 172900, Bozeman, MT 59717-2900, United States \\ Tel: 1- 229-391-4811_Email: vlane@abac.edu \\ Michael Frisina \\ Dept. of Animal \& Range Sciences, Montana State University \\ PO Box 172900, Bozeman, MT 59717-2900 \\ E-mail: mfrisina@bresnan.net
}


Received: March 10, 2016 Accepted: April 1, 2016

doi:10.5296/emsd.v5i1.9302

URL: http://dx.doi.org/10.5296/emsd.v5i1.9302

\begin{abstract}
We measured 328 sites in northern, central, and southern Montana and northern Wyoming during 2003 to test the competitive relationship of herbaceous cover in the interspaces to Wyoming big sagebrush (Artemisia tridentata wyomingensis) cover. Long term annual precipitation at all sites was approximately $31 \mathrm{~cm}$. Sagebrush and total herbaceous cover varied from 5 to 45 percent and 3.5 to 55 percent, respectively. Simple linear regression was the best fit model for predicting herbaceous cover from sagebrush cover using the highest $\mathrm{R}_{\mathrm{a}}^{2}$ values as the model selection criteria. In northern Montana, herbaceous vegetation was predicted by sagebrush cover with the following model: $\mathrm{Y}=37.4-0.61 \mathrm{X}\left(\mathrm{R}_{\mathrm{a}}^{2}=0.16, \mathrm{P}<\right.$ $0.001, \mathrm{n}=87)$. In central Montana, the model was $\mathrm{Y}=14.0-0.00 X\left(\mathrm{R}_{\mathrm{a}}^{2}=0.00, \mathrm{P}=1.0, \mathrm{n}=\right.$ 155). In southern Montana, the model was $\mathrm{Y}=35.9-0.39 \mathrm{X}\left(\mathrm{R}_{\mathrm{a}}^{2}=0.14, \mathrm{P}<0.001, \mathrm{n}=86\right)$. When all sites were combined, the best fit model was $\mathrm{Y}=23.7-0.15 \mathrm{X}\left(\mathrm{R}_{\mathrm{a}}^{2}=0.01, \mathrm{P}<0.061\right.$, $\mathrm{n}=328$ ). This analysis determined that only 1 percent of the variation in herbaceous vegetation cover was associated with Wyoming big sagebrush cover. Management suggestions to reduce Wyoming big sagebrush in order to increase long-term herbaceous production for greater sage-grouse (Centrocercus urophasianus) would not be recommended.
\end{abstract}

Keywords: Artemisia tridentata wyomingensis, Line intercept, Grass cover, Centrocercus urophasianus, Forb cover, Greater sage-grouse, Sage-grouse habitat.

\title{
1. Introduction
}

It has been suggested that dense sagebrush (Artemisia) cover lowers greater sage-grouse (Centrocercus urophasianus) habitat quality and biological diversity (Society for Range Management [SRM] 2006). The same publication states that sagebrush control can be used to enhance sage-grouse habitat by reducing sagebrush cover, which limits understory grass and forb production. Wright and Bailey (1982) recommended that removal of tall, thick sagebrush would release grasses and forbs from competition and result in increased yields for livestock grazing. Most of these suggestions are based on mountain big sagebrush (Artemisia tridentate tridentate) habitat types which are mesic and may have 30-40\% canopy cover. Bates and Davies (2014) did find that herbaceous production could be increased from $500 \mathrm{~kg} / \mathrm{ha}$ to 800 $\mathrm{kg} / \mathrm{ha}$ eleven years after burning in the more semi-arid Wyoming big sagebrush alliance. Davies and Bates (2014) concluded that treatments such as mowing and seeding did not increase the cover of perennial bunch grasses due to the invasion of non-native annual grasses. In contrast, Miller and Eddleman (2000) concluded that there was little evidence that fire could be used to enhance sage-grouse habitat where there was a balance of native shrubs and perennial grasses and forbs. This statement implies there are conditions where shrubs and herbaceous vegetation were "unbalanced" and therefore might be manipulated. Welch and Criddle (2003) examined the relationship between big sage cover and percent bare ground from several data sets and concluded that the calculated $R^{2}$ values averaging 0.05 for 
mountain big sagebrush (A. tridentata vaseyana) and Wyoming big sagebrush (A. $t$. wyomingensis) cover and perennial herbaceous cover were not significant. Most of these studies assume that there is a competitive relationship between herbaceous cover in the interspace and shrub cover. If this assumption is correct, one would expect to find a strong negative relationship between the two components across the landscape. We modeled the data from 328 sites to determine if there was a negative relationship between Wyoming big sagebrush cover and the herbaceous cover located in the interspaces between shrubs in Montana.

\section{Materials and Methods}

\subsection{Study Sites}

Our three study areas were separated by a total of approximately $355 \mathrm{~km}$ from the northern most to the southernmost locations sampled. Northern Montana samples were taken approximately $80 \mathrm{~km}$ south of Malta in southern Phillips County. Approximately 60 percent of this area is publicly owned by the U.S. Bureau of Land Management (BLM), the U.S. Fish and Wildlife Service (FWS), and the state of Montana (Moynahan 2004). Annual precipitation averaged $31 \mathrm{~cm}$ with peak precipitation between April and July (Western Regional Climate Center [WRCC] 2004). Soil taxonomic units that characterized this area included Absher, Elloam, and Thoeny (United States Department of Agriculture [USDA] 1981). Elevation varied from 600-1060 m. Wyoming big sagebrush was the dominant shrub at all sample locations. Plains silver sagebrush (Artemisia cana), greasewood (Sarcobatus vermiculatus), and rubber rabbitbrush (Chrysothamnus nauseosus) were relatively common at many sites. Western wheatgrass (Pascopyron smithii), and blue grama (Bouteloua gracilis) were the common dominant grasses, while Sandberg bluegrass (Poa secunda), needle-and-thread (Hesperostipa comata), and threadleaf sedge (Carex filifolia) were measured frequently. American vetch (Vicia americana), scarlet globemallow (Sphaeralcea coccinea), yellow sweetclover (Melilotus officinalis), and dandelion (Taraxacum officinale) were the most common forbs. Fringed sagewort (Artemisia frigida), clubmoss (Selaginella densa), and prickly pear (Opuntia polycantha) were also common.

Measurements in the central Montana counties of Golden Valley and Musselshell were taken in an area centered about $30 \mathrm{~km}$ northwest of Roundup, Montana. Precipitation in this area averages $31 \mathrm{~cm}$ annually (National Oceanic and Atmospheric Administration [NOAA] 2004). Soil taxonomic units common to this area include Abor, Neldore, and Vanda (United States Department of Agriculture [USDA] 2003). Elevation was between 826-1495 m. Wyoming big sagebrush was the dominant shrub although greasewood and plains silver sagebrush were also present. Western wheatgrass, Sandberg bluegrass, and blue grama were the dominant grasses, while green needlegrass (Nassella viridula), needle-and-thread, and threadleaf sedge were also common. Scarlet globemallow, wild onion (Allium), Hood's phlox (Phlox hoodii), and American vetch were the most abundant forbs.

Sampled sites in Bighorn County in southern Montana and adjacent Campbell County, Wyoming were mostly on private ranchland with some BLM and state land. Annual precipitation averaged $31 \mathrm{~cm}$ with peak precipitation occurring from April to June (National 


\section{Ml Macrothink}

Environmental Management and Sustainable Development

ISSN 2164-7682 2016, Vol. 5, No. 1

Oceanic and Atmospheric Administration [NOAA] 2003). Soil taxonomic units which characterize this area include Midway, Pierre, and Thedalun (United States Department of Agriculture, Natural Resource Conservation Service [USDA NRCS] 2004). The elevation range is $762-1314 \mathrm{~m}$. Wyoming big sagebrush was the dominant shrub, although plains silver sagebrush, skunkbrush sumac (Rhus aromatica), common juniper (Juniperus communis) and rubber rabbitbrush were also present. Sandberg bluegrass, western wheatgrass, and Japanese brome (Bromus japonicus) were the dominant grasses, although green needlegrass, prairie junegrass (Koeleria macrantha), and bluebunch wheatgrass (Psuedoroegneria spicata) were also common. Desert alyssum (Alyssum desertorum), Hood's phlox, scarlet globemallow, American vetch, dandelion, and western yarrow (Achillea millefolium) were the most common forbs.

\subsection{Sampling and Analysis}

All sampling was conducted during late spring and early summer of 2003 when herbaceous cover was near maximum levels. Sagebrush cover was measured with the line-intercept method (Canfield 1941) using the procedures recommended by Connelly and others (2003) and Wambolt, Frisina, Knapp and Frisina (2006). Line-intercepts were measured on two perpendicular $30 \mathrm{~m} \mathrm{~N}-\mathrm{S}$ and $\mathrm{E}-\mathrm{W}$ oriented transects. We measured sagebrush intercept in 3 $\mathrm{cm}$ units. We recorded openings in live foliage $\geq 3 \mathrm{~cm}$ as nonsagebrush intercepts. Thus, we excluded both open spaces and dead portions of the plant. We obtained all measurements by vertically projecting a plumb bob from the transect line to plants to determine what intercepts from ground level to crown were directly beneath the line.

Herbaceous understory cover was measured using twenty 20 x $50 \mathrm{~cm}$ quadrats (Daubenmire 1959). The same N-S, E-W transects used to measure sagebrush cover were used to locate the quadrats for herbaceous sampling at $3 \mathrm{~m}$ intervals.

A number of linear and non-linear models were tested to determine the "best fit" relationship between sagebrush cover and herbaceous cover. Linear, quadratic, cubic, inverse, first order, sigmoidal, exponential decay, exponential growth and polynomial models were tested using SigmaPlot (2004). Maximum $R_{a}^{2}$ values were used to determine which model best fit our data.

\section{Results and Discussion}

All sites ( $\mathrm{n}=328)$ averaged 17\% Wyoming big sagebrush cover and 23\% herbaceous cover. Simple linear regression models for all data sets resulted in the maximum $R_{a}^{2}$ values. In northern Montana, as sagebrush cover increased, herbaceous cover decreased $\left(R_{a}^{2}=0.16, P\right.$ $<0.001, n=87$ ), but only 16 percent of the variation in herbaceous cover was accounted for with change in sagebrush cover (figure.1).

In central Montana, we found no relationship $\left(R_{a}^{2}=0.00, P=1.0, n=155\right)$ between Wyoming big sagebrush cover and herbaceous cover (figure 1). We conclude that in this region, herbaceous cover in the interspaces is not influenced by Wyoming big sagebrush cover. 
In southern Montana, herbaceous cover declined as sagebrush cover increased, but, 86 percent of the variation in herbaceous cover was not accounted for by sagebrush cover $\left(R_{a}^{2}=\right.$ $0.14, P<0.001, n=86$ ) (figure 1).

When all 328 sites were combined, a simple linear equation best explained the relationship between Wyoming big sagebrush cover and herbaceous cover (figure 1). There is a slight inverse relationship between the two variables (figure 1), but the $R_{a}^{2}=0.01,(P<0.06)$ indicates that across Montana and adjacent Wyoming, the variability in interspace herbaceous cover cannot be explained by the amount of sagebrush cover.
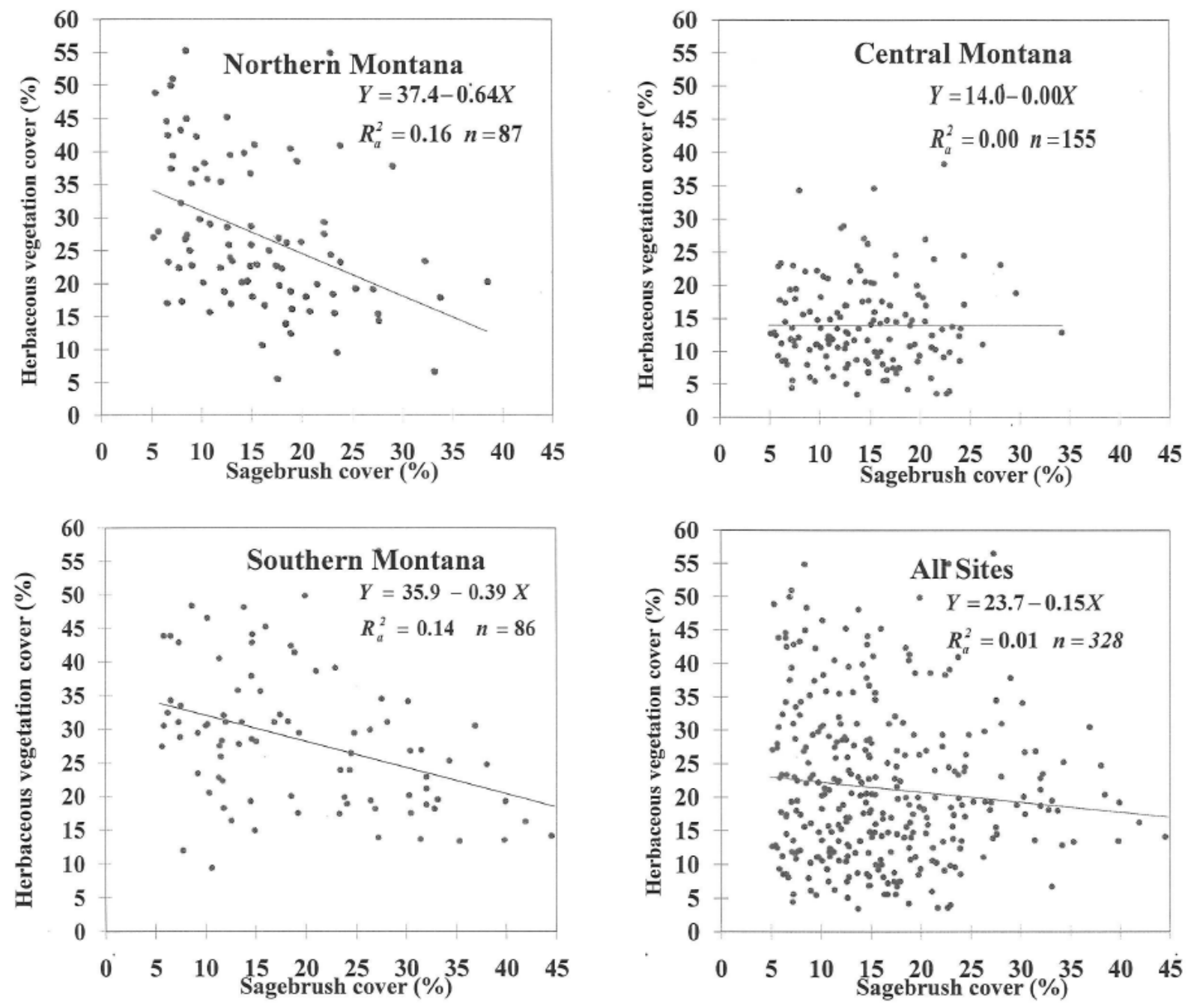

Figure 1. Relationship of Wyoming big sagebrush cover to herbaceous cover in northern, central, and southern Montana and over all sites.

Some authors (Baxter 1996; SRM 2006) indicated that when big sagebrush cover increases over 12 to 15 percent, the understory production of other plants decreases as cover increases. However, Welch and Criddle (2003) found no significant relationship between sagebrush cover and bare ground $\left(R^{2}=0.0003\right)$. An additional concern arises from the fact that Baxter (1996) and SRM (2006) do not clarify the details of their sagebrush cover measurements and, 
therefore, it is possible that their 12 to 15 percent sagebrush cover would be much less using our methodology (Wambolt, Frisina, Knapp and Frisina 2006).

Moynahan (2004) examined grass and forb cover from 2001 to 2003 in our northern Montana study area as part of a sage-grouse brood survival study. Perennial grass cover did not change appreciably in three years, but forb cover nearly doubled, largely due to the biennial yellow sweetclover responding to favorable growing conditions. Brood survival rates increased 3.5 fold from 2001 (drought year) to 2003 likely due to the increased abundance of herbaceous cover. Moynahan's (2004) findings in combination with our results indicate that precipitation has a much greater influence on herbaceous cover than does the amount of sagebrush cover in the semi-arid Wyoming big sagebrush alliance. Welch and Criddle (2003) also concluded that precipitation, plant species, and soil properties influenced ground and perennial grass cover more than sagebrush cover. Davies and Bates (2014) concluded that reducing Wyoming big sagebrush cover in plant communities with depleted understories do more harm than good.

\section{Conclusion}

It has been suggested that sagebrush control can be used to enhance herbaceous vegetation (SRM 2006). We determined that across our 328 study plots a weak linear relationship exists between Wyoming big sagebrush cover and herbaceous cover $(Y=23.7-0.15 X)$. However, 99 percent of the variation in herbaceous cover is not accounted for by changes in sagebrush cover alone $\left(R_{a}^{2}=0.01, P<0.061\right)$. These results suggest that there is very little direct competition between herbaceous cover in the spaces between sagebrush plants and the cover of Wyoming big sagebrush. Prescribed burning, prescribed grazing, herbicides and mechanical treatments have all been advocated to improve sage-grouse habitat where it is hypothesized that dense sagebrush cover limits herbaceous biomass (SRM 2006). Since Wyoming big sagebrush cover averaged $17 \%$ across all sites, and there were only $7 \%(24 / 328)$ of the sites where shrub cover exceeded $30 \%$, it appears that there is very little need to reduce sagebrush cover. Removing Wyoming big sagebrush cover to increase herbaceous vegetation to enhance sage-grouse brood survival, does not appear to be a sound practice since the shrub is a key nesting and winter component.

\section{Acknowledgement}

Funding and land for this research was provided by the Bureau of Land Management field offices in Montana, Montana Fish, Wildlife and Parks, and the Montana Agricultural Experiment Station

\section{References}

Bates, J. D., \& K.W. Davies. (2014). Cattle Grazing and Vegetation Succession on Burned Sagebrush Steppe. Rangeland Ecology \& Management, 67(4), 412-422. http://dx.doi.org/10.2111/REM-D-14-00011.1.

Baxter, G. (1996). Improving rangeland health by thinning dense sagebrush stands with tebuthiuron (spike 20P). In: Evans, Keith K, compo 1996. Sharing common ground on western rangelands: proceedings of a livestock/big game symposium; 1996 February 26-28; 
Sparks, NV. Gen. Tech. Rep. INT-GTR-343. Ogden, UT: U.S. Department of Agriculture, Forest Service, Intermountain Research Station: 60-62.

Canfield, R. H. (1941). Application of the line interception method in sampling range vegetation. Journal of Forestry, 39(4), 388-394.

Davies, K. W., \& J. D. Bates. (2014). Attempting to Restore Herbaceous Understories in Wyoming Big Sagebrush Communities with Mowing and Seeding. Restoration Ecology, 22(5), 608-615. http://dx.doi.org/10.1111/rec.12110

Daubenmire, R. (1959). A canopy-coverage method of vegetational analysis. Northwest Science, 33(1), 43-64.

Miller, R. F., \& Eddleman, L. (2000). Spatial and temporal changes of sage grouse habitat in the sagebrush biome. Corvallis, OR: Oregon State University, Agricultural Experiment Station.

Moynahan, B. J. (2004). LANDSCAPE-SCALE FACTORS AFFECTING POPULATION DYNAMICS (Doctoral dissertation, The University of Montana).

National Oceanic and Atmospheric Administration (NOAA). (2003). Annual climatological summary, Decker, Montana. Available: http://cdo.ncdc.noaa.gov/ancsum/ACS.

National Oceanic and Atmospheric Administration (NOAA) (2004). Annual climatological summary, Roundup, Montana. Available: http://cdo.ncdc.noaa.gov/ancsum/ACS.

SigmaPlot 6. 0. (2004). Users Guide. SPSS Inc. 233 South Wacker Drive, $11^{\text {th }}$ Floor, Chicago, IL 60606-6307.

Society for Range Management (SRM). (2005). Ecology and management of sage-grouse and sage-grouse habitat: Issue paper created by the Society for Range Management.

United States Department of Agriculture (USDA). (2003). Soil survey of Musselshell County, Montana. Natural Resource Conservation Service, Bozeman, MT.

United States Department of Agriculture (USDA). (1981). Technical guide. Section II-E-8. USDA-SCS-MT.

United States Department of Agriculture Natural Resource Conservation Service (USDA NRCS). (2004). Soil data mart. Available: http://soildatamart.nrcs.usda.gov

Wambolt, C. L., Frisina, M. R., Knapp, S. J., \& Frisina, R. M. (2006). Effect of method, site, and taxon on line-intercept estimates of sagebrush cover. Wildlife Society Bulletin, 34(2), 440-445. http://dx.doi.org/10.2193/0091-7648(2006)34[440:EOMSAT]2.0.CO;2

Welch, B. L., \& Criddle, C. (2003). Countering misinformation concerning big sagebrush. Res. Pap. RMRS-RP-40. Ogden, UT: US Department of Agriculture, Forest Service, Rocky Mountain Research Station.

Western Regional Climate Center. (2005). Roundup, Montana Climate Summary. Available at: http://www.wrcc.dri.edu/summary/climsmmt.html. Accessed March 3, 2005. 


\section{Macrothink}

Environmental Management and Sustainable Development

ISSN 2164-7682

Wright, H. A., \& Bailey, A. W. (1982). Fire ecology: United States and southern Canada. John Wiley \& Sons.

\section{Copyright Disclaimer}

Copyright for this article is retained by the author(s), with first publication rights granted to the journal.

This is an open-access article distributed under the terms and conditions of the Creative Commons Attribution license (http://creativecommons.org/licenses/by/3.0/). 